\title{
On the Impact of Economic Complexity on the Relationship Between GRP Trajectories and Technical Efficiency
}

\author{
Afanasiev M. Kudrov A. \\ Central Economics and Mathematics Institute of the Russian Academy of Sciences, Russia, Moscow \\ *Corresponding author. Email: miafan@cemi.rssi.ru
}

\begin{abstract}
With other factors unchanged, an increase in the technical efficiency of the region leads to an increase in its GRP. However, the GRP trajectory is not necessarily interconnected with the trajectory of its technical efficiency. The hypothesis is tested that for groups of regions with a close structure of strong sectors, with fairly high group estimates of economic complexity and group estimates of the relationship of GRP trajectories and technical efficiency trajectories, economic complexity affects the degree of statistical interconnection of trajectories. With low group assessments of the trajectories interconnection, or low group assessments of economic complexity, the level of interconnection between GRP trajectories and technical efficiency trajectories depends on the structure of strong sectors that determines the specifics of the group.

Keywords: technical efficiency, economic complexity, regional economy, econometric modeling
\end{abstract}

\section{INTRODUCTION}

The aim of the study is to analyze the relationship between GRP trajectories and technical efficiency trajectories, taking into account the structures of strong sectors of the regions and the concept of economic complexity.

The methodology for assessing the technical efficiency of production is based on the concept of a stochastic border. The main provisions of the concept of stochastic boundary production function were first presented in (Aigner, Lovell, Schmidt, 1977; Meeusen, van den Broeck, 1977). The stochastic border methodology takes into account the fact that some related factors have a random effect on the production process, reducing its effectiveness. In order to take this effect into account, along with the deterministic component that characterizes the influence of the main factors of production, the production function includes a random component that simulates the influence of related factors, including efficiency factors. Authors' experimental calculations for estimating the parameters of a stochastic boundary production function by the maximum likelihood method confirmed the possibility of its use for evaluating production efficiency (Aivazian, Afanasiev, 2014).

In accordance with the concept of stochastic frontier, technical efficiency is considered as the ratio of actual production to potential (Kumbhakar, Lovel, 2004; Aivazian, Afanasiev, 2014). The higher the technical efficiency, the closer the actual GRP to the potential. With other factors unchanged, an increase in the technical efficiency of the region leads to an increase in its GRP. However, in addition to technical efficiency, other factors influence the GRP path of the region. Therefore, the GRP trajectory is not necessarily interconnected with the trajectory of its technical efficiency.

To calculate the economic complexity index and describe the structure of strong sectors of the region's economy, the concept of revealed comparative advantages (Balassa, 1965), a well-known approach to assessing economic complexity (Hausmann et al., 2011; Hidalgo, Hausmann, 2009; Lyubimov et al., 2017) are used) and its author's modification based on the use of tax revenue data by sector of the economy. Characteristics of the region's economy diversification level were obtained, identifying strong sectors whose products the region produces at the level of identified comparative advantages, the index of economic complexity of the regions was calculated, and thirteen groups of regions that were similar in structure to strong sectors were identified using the "minimum spanning tree" (Afanasiev and Kudrov, 2020) These groups have two properties: each group corresponds to the structure of a minimal spanning tree; for each group, one, two or three sectors were identified that are strong in the structure of economic complexity for all regions of only this group.

One of the issues of project management related to ensuring the sustainability of regional development: - Does the degree of interconnection between GRP trajectories and technical efficiency trajectories depend on the complexity of the regional economy? At the regional level, there is no linear relationship between the correlation coefficients of GRP trajectories and technical efficiency trajectories on the one hand and the economic complexity index on the other hand - the correlation coefficient is 0.057 . 
Hypothesis 1 is tested in this work: with fairly high group estimates of economic complexity and group estimates of the relationship between GRP trajectories and technical efficiency trajectories for groups of regions with a close structure of strong sectors, economic complexity affects the degree of statistical interconnection of trajectories.

\section{METHODS}

Prerequisite 1. The statistical relationship between the GRP trajectories and the technical efficiency trajectories is stable relative to the group of regions for which the technical efficiency estimates are calculated.

To construct the trajectories of technical efficiency, a power-law production function is used with logarithmically linearly time-dependent coefficients of the form:

$\ln R_{i t}=\beta_{0}+\alpha_{0} t+\left(\beta_{1}+\alpha_{1} t\right) \ln K_{i t}+\left(\beta_{2}+\alpha_{2} t\right) \ln L_{i t}+v_{i t}-u_{i t}$ (1)

where $R_{i t}$ - GRP of region $i$ at time $t ; K_{i t}$ - the volume of capital expenditures of region $i$ at time $t$, - the volume of labor costs of region $i$ at time $t, v_{i} \in N\left(0, \sigma_{v}^{2}\right) ; u_{i} \in N^{+}\left(0, \sigma_{u}^{2}\right) \quad$ The random component $\varepsilon_{i t}=v_{i t}-u_{i t}$ reflects the results of exposure to uncertainties and efficiency factors. In accordance with the concept of a stochastic border, an estimate of the technical efficiency of production of region $i$ at time $t$, is the conditional mathematical $T E_{i t}=\mathrm{E}\left(\exp \left\{u_{i t}\right\} \mid \varepsilon_{i t}\right)$ expectation (Kumbhakar, Lovell, 2004). The advantages of using a power-law production function and the methodology of its specification are presented in (Aivazian, Afanasiev, Rudenko, 2017).

To test hypothesis 1 , for each group of regions with a similar structure of strong sectors, two estimates were obtained: a group estimate of economic complexity and a group estimate of the statistical relationship of trajectories. A group assessment of economic complexity was obtained on the basis of the economic complexity index, which was compiled in accordance with (Afanasiev and Kudrov,
2020) and is shown in column 4 of Table 3 . This estimate is calculated as the average value of the indices of economic complexity of the regions included in the group. For stability estimates, the minimum and maximum values of the indices in the group were excluded. It should be noted that the ordering of groups is preserved if estimates of economic complexity are calculated as the average value of the ranks of the regions included in the group.

For all regions, estimates of the correlation coefficients of GRP trajectories and technical efficiency trajectories were obtained. For each group of regions close in structure to strong sectors, group estimates of the trajectories relationship are constructed as the average values of the correlation coefficients of these trajectories for the regions included in the group. Groups of regions with fairly high group estimates of economic complexity and group estimates of the relationship of GRP trajectories and technical efficiency trajectories are identified. For these groups, a correlation analysis of estimates of economic complexity and estimates of the relationship of GRP trajectories and technical efficiency trajectories was carried out.

\section{RESULTS}

When calculating the parameters of the production function (1) and estimates of technical efficiency, the data of Rosstat for the period from 2010 to 2017 were used for the following indicators: GRP; value of fixed assets as an estimate of capital expenditures; the number of economically active population as the volume of labor. As a result of the calculations, estimates of the production function parameters and technical efficiency of 80 regions for the period from 2010 to 2017 were obtained. All parameter estimates presented in Table 1, except for the constant, are significant at the $1 \%$ level. When forming the trajectories of technical efficiency, the obtained estimates were normalized for each year of the considered period so that the normalized estimates have an average value of 0 and a standard deviation of 1 . With this normalization, estimates of technical efficiency are comparable for different years of the period under consideration.

Table 1 Estimates of the production function parameters

\begin{tabular}{|l|l|l|l|l|l|l|l|l|}
\hline & $\beta_{0}$ & $\alpha_{0}$ & $\beta_{1}$ & $\alpha_{1}$ & $\beta_{2}$ & $\alpha_{2}$ & $\sigma_{v}$ & $\sigma_{u}$ \\
\hline Coef. & -0.135 & 0.118 & 0.853 & -0.017 & 0.180 & 0.019 & 0.215 & 0.005 \\
\hline Std. Err. & 0.245 & 0.052 & 0.029 & 0.007 & 0.036 & 0.008 & 0.006 & 0.139 \\
\hline Z & -0.55 & 2.28 & 29.27 & -2.51 & 5.00 & 2.39 & & \\
\hline
\end{tabular}

Number of obs $=640$, Log likelihood $=76.152$ 
The normalized values of GRP of 80 regions for the period from 2010 to 2017 are calculated and GRP trajectories are generated for the considered time period. Figure 1 shows the values of the correlation coefficients of the GRP trajectories and technical efficiency, sorted in descending order. For 63 regions out of 80, correlation coefficients are positive. For 54 regions - above 0.3 . For most regions, there is a significant statistical relationship between GRP trajectories and technical efficiency trajectories.

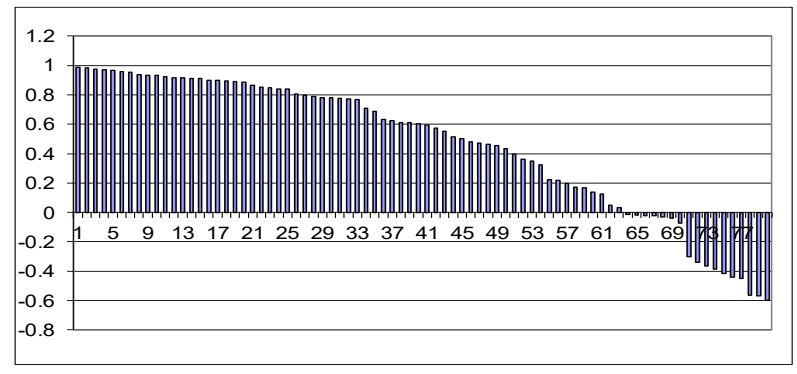

Figure 1 On the abscissa axis - the serial number of the region. On the ordinate axis - the values of the correlation coefficients of the GRP trajectories and technical efficiency trajectories sorted in decreasing order.

The minimum spanning tree constructed in accordance with (Afanasiev and Kudrov, 2020) using the Kruskal algorithm (Kruskal, 1956) is shown in Fig. 2.

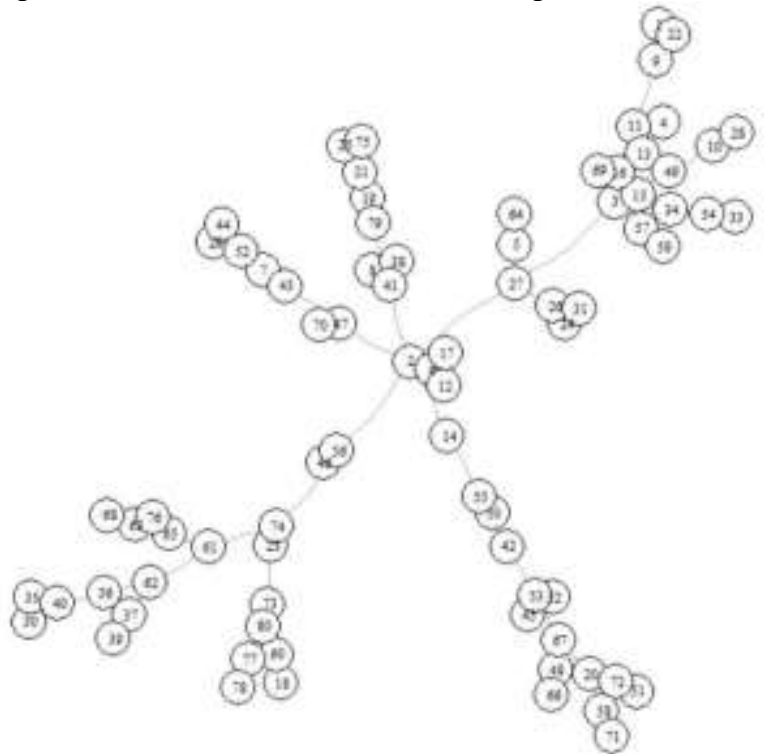

Figure 2 Minimum spanning tree for grouping regions according to the structure of complex sectors.

In Figure 2, each vertex of the tree characterizes the subject of the Russian Federation. The vertices are numbered in the order used in column 1 of Table 3 . Arc length is the proximity of two regions in the structure of strong sectors. There are one or several groups of regions on each branch of the tree that are similar in structure of economic complexity. Based on visualization and expert analysis of the minimum spanning tree, thirteen groups of regions are identified, indicated in column 3 of Table 3 .
Group estimates of economic complexity and the relationship of trajectories for thirteen groups of regions are given in columns 3 and 4 of Table 2 .

Table 2 Characteristics of economic complexity and the relationship of trajectories for groups of regions similar in structure to strong sectors.

\begin{tabular}{|c|c|c|c|}
\hline $\begin{array}{l}\text { Group } \\
\text { number }\end{array}$ & $\begin{array}{c}\text { The number } \\
\text { of regions in } \\
\text { the group }\end{array}$ & $\begin{array}{l}\text { Group } \\
\text { complexity } \\
\text { rating }\end{array}$ & \begin{tabular}{|c|} 
Group \\
assessment of \\
the relationship \\
of trajectories
\end{tabular} \\
\hline (1) & (2) & (3) & (4) \\
\hline 1 & 3 & 0.786 & 0.825 \\
\hline 2 & 10 & 0.609 & 0.661 \\
\hline 3 & 7 & 0.593 & 0.534 \\
\hline 4 & 7 & 0.466 & 0.101 \\
\hline 5 & 4 & 0.439 & 0.492 \\
\hline 6 & 4 & 0.292 & 0.632 \\
\hline 7 & 6 & 0.292 & -0.073 \\
\hline 8 & 7 & 0.260 & 0.416 \\
\hline 9 & 5 & 0.212 & 0.509 \\
\hline 10 & 5 & 0.211 & 0.318 \\
\hline 11 & 5 & -0.025 & 0.468 \\
\hline 12 & 11 & -1.064 & 0.695 \\
\hline 13 & 6 & -1.313 & 0.367 \\
\hline
\end{tabular}

To test hypothesis 1 , groups 4 and 7 with low estimates of the relationship of trajectories, and also groups 12 and 13 with low estimates of economic complexity were excluded from consideration. The characteristics of the remaining nine groups with relatively high group estimates of the relationship of trajectories and economic complexity are presented in Fig. 3. 


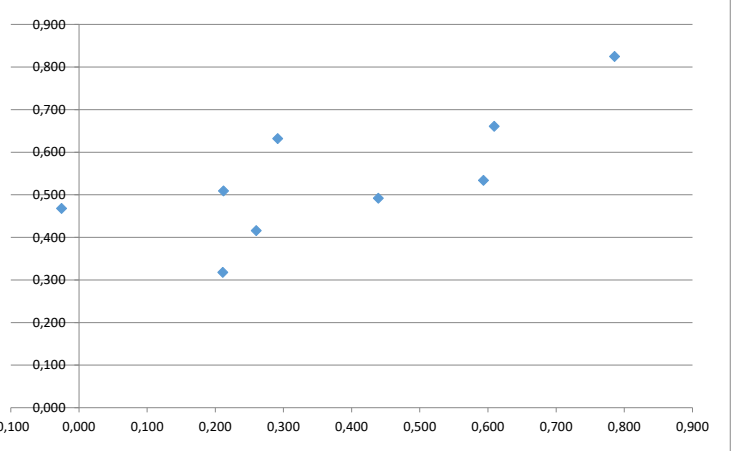

Figure 3 Along the abscissa axis - an assessment of the economic complexity of the group, along the ordinate axis - an assessment of the relationship of trajectories

Pearson's correlation coefficient of economic complexity estimates of nine groups of regions and estimates of the trajectories relationship is 0.725 . Spearman's rank correlation coefficient is 0.817 .

\section{DISCUSSION}

It can be concluded that the test results do not contradict hypothesis 1 . However, a high correlation of estimates of economic complexity and the relationship of trajectories is observed only for nine out of thirteen groups. Basically, these are groups of regions with strong engineering and manufacturing sectors, as well as coal and metal ore mining. For two groups: 4 and 7 with fairly high estimates of economic complexity, estimates of the statistical relationship of GRP trajectories and technical efficiency trajectories are small. As shown in (Aivazian, Afanasiev, 2020), group 4 regions specialize in dairy production. The regions of group 7 are in food production. For two groups 12 and 13, with low estimates of economic complexity, a strong interconnection of trajectories is observed. Group 12 regions specialize in oil and natural gas production. Group 13 regions specialize in administrative activities, air transport and construction. Thus, the assessment of the interconnection of trajectories level is determined not only by economic complexity, but also by the structure of the strong sectors of the group.

To substantiate the correctness of the premise 1 use, the characteristics of the trajectories relationship are checked for stability. Of the entire set of regions, 26 were selected for which the correlation between the GRP trajectory and technical efficiency is insignificant (these estimates are shown in italics in column 5 of Table 3 ). 13 regions were randomly added to them, for which the correlation coefficients of the trajectories are higher than 0.3. As a result, a control group of 39 regions was formed. For this control group, a production function of the form (1) was constructed, estimates of technical efficiency were obtained, and corresponding control trajectories of technical efficiency were constructed. A linear regression of the previously calculated correlation coefficients of the 39 regions trajectories of the control group from column 5 of Table 3 of the application to the new correlation coefficients from column 6 of Table 3 is constructed. In this regression, the coefficient for the variable is 0.997 (standard error $0.043, \mathrm{R} 2=0.935$ ). It can be concluded that the weak statistical relationship of the GRP trajectories and the technical efficiency trajectories is stable relative to the control group of regions. This result confirms the validity of premise 1 and the conclusion about the results of testing hypothesis 1 .

Table 3 Estimates of economic complexity and the relationship of the trajectories

Column Name:

(1) - region number,

(2) - name of the region,

(3) - group number of the region according to the structure of strong sectors,

(4) - index of economic complexity,

(5) - correlation coefficients of the GRP trajectory and technical efficiency,

(6) - correlation coefficients for the control group.

\begin{tabular}{|l|l|l|l|l|l|}
\hline$(1)$ & \multicolumn{1}{|c|}{$(2)$} & \multicolumn{1}{c|}{$(3)$} & \multicolumn{1}{c|}{$(4)$} & \multicolumn{1}{c|}{$(5)$} & $(6)$ \\
\hline 1 & Belgorod region & 1 & 0.920 & 0.774 & \\
\hline 22 & Vologda region & 1 & 0.786 & 0.768 & \\
\hline 9 & Lipetsk region & 1 & 0.662 & 0.932 & \\
\hline 33 & $\begin{array}{l}\text { Volgograd } \\
\text { region }\end{array}$ & 2 & 0.707 & 0.968 & \\
\hline 13 & Smolensk region & 2 & 0.388 & 0.79 & \\
\hline 11 & Oryol region & 2 & 0.608 & $\mathbf{0 . 1 9 8}$ & 0.367 \\
\hline 54 & Saratov region & 2 & 0.329 & $\mathbf{- 0 . 0 1 7}$ & 0.072 \\
\hline 16 & Tula region & 2 & 0.409 & 0.985 & \\
\hline 59 & $\begin{array}{l}\text { Chelyabinsk } \\
\text { region }\end{array}$ & 2 & 0.727 & 0.912 & \\
\hline 57 & $\begin{array}{l}\text { Sverdlovsk } \\
\text { region }\end{array}$ & 2 & 0.674 & $\mathbf{0 . 0 3 2}$ & -0.053 \\
\hline 3 & Vladimir region & 2 & 0.771 & 0.936 & \\
\hline 4 & Voronezh region & 2 & 0.652 & 0.896 & \\
\hline 34 & Rostov region & 2 & 0.708 & 0.914 & \\
\hline 12 & Ryazan region & 3 & 0.776 & 0.502 & \\
\hline 38 & $\begin{array}{l}\text { Karachay- } \\
\text { Cherkess }\end{array}$ & 3 & 0.414 & 0.839 & \\
\hline 2 & Republic & 3 & 0.542 & 0.514 & \\
\hline 8 & Kursk region & 3 & 0.686 & $\mathbf{0 . 1 6 7}$ & 0.144 \\
\hline 17 & Yaroslavl region & 3 & 0.453 & 0.603 & 0.554 \\
\hline 6 & Kaluga region & 3 & 0.732 & 0.891 & \\
\hline 41 & Stavropol region & 3 & 0.553 & $\mathbf{0 . 2 2 1}$ & 0.084 \\
\hline 44 & $\begin{array}{l}\text { Republic } \\
\text { Mordovia }\end{array}$ & 4 & 0.599 & $\mathbf{- 0 . 0 3 9}$ & 0.043 \\
\hline
\end{tabular}




\begin{tabular}{|c|c|c|c|c|c|}
\hline 43 & $\begin{array}{l}\text { Republic of Mari } \\
\text { El }\end{array}$ & 4 & 0.507 & 0.17 & 0.303 \\
\hline 47 & Chuvash republic & 4 & 0.569 & 0.633 & \\
\hline 7 & Kostroma region & 4 & 0.284 & -0.303 & -0.26 \\
\hline 70 & Omsk region & 4 & 0.372 & 0.69 & \\
\hline 52 & Penza region & 4 & 0.646 & 0.125 & 0.058 \\
\hline 29 & $\begin{array}{l}\text { Republic } \quad \text { of } \\
\text { Adygeya }\end{array}$ & 4 & 0.222 & -0.566 & -0.426 \\
\hline 55 & $\begin{array}{l}\text { Ulyanovsk } \\
\text { region }\end{array}$ & 5 & 0.324 & -0.364 & -0.309 \\
\hline 42 & $\begin{array}{l}\text { Republic of } \\
\text { Bashkortostan }\end{array}$ & 5 & -0.305 & 0.976 & \\
\hline 50 & $\begin{array}{l}\text { Nizhny } \\
\text { Novgorod region }\end{array}$ & 5 & 0.739 & 0.454 & \\
\hline 14 & Tambov region & 5 & 0.554 & 0.901 & \\
\hline 76 & Amur region & 6 & 0.095 & 0.848 & \\
\hline 65 & $\begin{array}{l}\text { Trans-Baikal } \\
\text { region }\end{array}$ & 6 & 0.113 & 0.711 & \\
\hline 63 & $\begin{array}{ll}\text { Republic } & \text { of } \\
\text { Khakassia } & \\
\end{array}$ & 6 & 0.470 & -0.021 & 0.008 \\
\hline 68 & Kemerovo region & 6 & 0.630 & 0.989 & \\
\hline 26 & Novgorod region & 7 & 0.092 & 0.614 & \\
\hline 24 & Leningrad region & 7 & 0.214 & 0.473 & \\
\hline 5 & Ivanovo region & 7 & 0.437 & -0.015 & -0.1 \\
\hline 31 & Krasnodar region & 7 & -0.165 & -0.599 & -0.623 \\
\hline 64 & Altai region & 7 & 0.523 & -0.57 & -0.623 \\
\hline 27 & Pskov region & 7 & 0.423 & -0.34 & -0.216 \\
\hline 37 & $\begin{array}{l}\text { Kabardino- } \\
\text { Balkaria republic }\end{array}$ & 8 & 0.452 & 0.779 & 0.757 \\
\hline 62 & Republic of Tyva & 8 & 0.130 & 0.917 & \\
\hline 35 & $\begin{array}{l}\text { Republic } \\
\text { Dagestan }\end{array}$ & 8 & 0.286 & 0.137 & -0.101 \\
\hline 39 & $\begin{array}{lr}\text { Republic } & \text { of } \\
\text { North Ossetia- } \\
\text { Alania }\end{array}$ & 8 & 0.087 & 0.483 & \\
\hline 30 & $\begin{array}{ll}\text { Republic } & \text { of } \\
\text { Kalmykia } & \end{array}$ & 8 & 0.442 & 0.05 & 0.049 \\
\hline 36 & $\begin{array}{l}\text { Republic } \\
\text { Ingushetia }\end{array}$ & 8 & 0.192 & 0.576 & 0.594 \\
\hline 40 & $\begin{array}{l}\text { Chechen } \\
\text { Republic }\end{array}$ & 8 & 0.249 & -0.029 & -0.117 \\
\hline 25 & $\begin{array}{l}\text { Murmansk } \\
\text { region }\end{array}$ & 9 & 0.216 & 0.933 & \\
\hline 75 & $\begin{array}{l}\text { Khabarovsk } \\
\text { region }\end{array}$ & 9 & -0.341 & 0.553 & \\
\hline 19 & $\begin{array}{l}\text { Republic of } \\
\text { Karelia }\end{array}$ & 9 & 0.377 & -0.075 & 0.012 \\
\hline 21 & $\begin{array}{l}\text { Arkhangelsk } \\
\text { region }\end{array}$ & 9 & 0.043 & 0.326 & 0.371 \\
\hline 79 & $\begin{array}{l}\text { Jewish } \\
\text { Autonomous } \\
\text { region }\end{array}$ & 9 & 0.570 & 0.806 & 0.798 \\
\hline
\end{tabular}

\begin{tabular}{|c|c|c|c|c|c|}
\hline 28 & St. Petersburg & 10 & -1.497 & -0.022 & 0.082 \\
\hline 10 & Moscow region & 10 & 0.037 & 0.852 & \\
\hline 69 & $\begin{array}{l}\text { Novosibirsk } \\
\text { region }\end{array}$ & 10 & 0.358 & 0.925 & \\
\hline 15 & Tver region & 10 & 0.238 & 0.219 & 0.173 \\
\hline 49 & Kirov region & 10 & 0.638 & -0.385 & -0.308 \\
\hline 74 & Primorsky region & 11 & -0.094 & 0.868 & \\
\hline 23 & $\begin{array}{l}\text { Kaliningrad } \\
\text { region }\end{array}$ & 11 & -0.221 & 0.351 & 0.437 \\
\hline 46 & Udmurt Republic & 11 & -0.197 & 0.78 & \\
\hline 56 & Kurgan region & 11 & 0.542 & -0.443 & -0.472 \\
\hline 61 & $\begin{array}{l}\text { The republic of } \\
\text { Buryatia }\end{array}$ & 11 & 0.215 & 0.783 & 0.735 \\
\hline 48 & Permsky Krai & 12 & 0.340 & 0.842 & \\
\hline 32 & Astrakhan region & 12 & -2.436 & 0.899 & \\
\hline 51 & Orenburg region & 12 & -3.332 & 0.96 & \\
\hline 67 & Irkutsk region & 12 & -0.053 & 0.953 & \\
\hline 66 & $\begin{array}{l}\text { Krasnoyarsk } \\
\text { region }\end{array}$ & 12 & -0.469 & 0.887 & \\
\hline 53 & Samara region & 12 & -0.010 & 0.912 & \\
\hline 20 & Komi Republic & 12 & -0.749 & 0.973 & \\
\hline 58 & Tyumen region & 12 & -2.719 & 0.799 & \\
\hline 71 & Tomsk region & 12 & -1.384 & -0.415 & -0.439 \\
\hline 72 & $\begin{array}{l}\text { Republic of } \\
\text { Sakha (Yakutia) }\end{array}$ & 12 & -1.234 & 0.397 & \\
\hline 45 & $\begin{array}{l}\text { Republic of } \\
\text { Tatarstan }\end{array}$ & 12 & -0.524 & 0.434 & 0.367 \\
\hline 18 & Moscow & 13 & -4.510 & 0.361 & -0.029 \\
\hline 73 & $\begin{array}{l}\text { Kamchatka } \\
\text { region }\end{array}$ & 13 & -0.231 & 0.463 & 0.437 \\
\hline 77 & Magadan region & 13 & -0.565 & 0.61 & 0.6 \\
\hline 80 & $\begin{array}{l}\text { Chukotka } \\
\text { Autonomous } \\
\text { Okrug }\end{array}$ & 13 & -0.620 & -0.451 & -0.353 \\
\hline 78 & Sakhalin region & 13 & -3.403 & 0.596 & 0.571 \\
\hline 60 & Altai Republic & 13 & -0.663 & 0.623 & 0.659 \\
\hline
\end{tabular}

\section{CONCLUSION}

Grouping of the regions of the Russian Federation by the structure of strong sectors has been completed. The statistical relationship of the GRP trajectories and the trajectories of technical production efficiency for the constituent entities of the Russian Federation is estimated. For each group of regions, an assessment of the relationship of the trajectories and an assessment of the economic complexity of the group are obtained.

The results are obtained that do not contradict the hypothesis that, with sufficiently high group estimates of 
[5] B. Balassa, Lafayrade Liberalization and "Revealed" Comparative Advantage, The Manchester School, Vol. 33 (1965) P. 99-123.

[6] R. Hausmann, C. Hidalgo, S. Bustos, M. Coscia, A. Simoes, M.A. Yildirim (2011) The Atlas of Economic Complexity: Mapping Pathsto Prosperity. Cambridge: Center for International Development, Harvard University, MIT.

[7] C. A. Hidalgo, R. Hausmann (2009) The building blocks of economic complexity. Proceedings of the National Academy of Sciences, 106(26), 10570-10575.

[8] S. Kumbhakar, K. Lovell (2004) Stochastic frontier analysis. Cambridge University Press.

[9] J. B. Kruskal (1956) On the Shortest Spanning Subtree of a Graph and the Traveling Salesman Problem. Proceedings of the American Mathematical Society, 7(1).

[10] I.L. Lyubimov, M.A. Gvozdeva, M.V. Kazakova, K.V. Nesterova (2017) Economic Complexity of Russian Regions and their Potential to Diversify, NEA Journal, № 2 (34), c. 94-122 (in Russian).

[11] W. Meeusen, J. van den Broeck, (1977) Efficiency Estimation from Cobb-Douglas Production Functions With Composed Error. International Economic Review, $18,435-444$.

[1] D.J. Aigner, C.A.K. Lovell, P. Schmidt, Formulation and Estimation of Stochastic Frontier Production Function Models. Journal of Econometrics, 6 (1977) p. 21-37.

[2] S. A. Aivazian, M. Yu. Afanasiev Modelirovaniye proizvodstvennogo potentsiala na osnove kontseptsii stokhasticheskoy granitsy. Metodologiya, rezul'taty empiricheskogo analiza. KRASNAD, M., (2014), s.352.

[3] S.A. Aivazian, M.Y. Afanasiev, V.A. Rudenko (2017) Specification of a stochastic production function model in the extended class of stochastic frontier models, Modeling of artificial Intelligence, Vol. 4, №1, pp. 21-28.

[4] M. Yu. Afanasiev, A. A. Kudrov (2020) Struktury sil'nykh sektorov sub"yektov RF i otsenki ikh ekonomicheskoy slozhnosti. Materialy II mezhdunarodnoy nauchno-prakticheskoy konferentsii «Sovremennyye trendy upravleniya i tsifrovaya ekonomika: ot regional'nogo razvitiya $\mathrm{k}$ global'nomu ekonomicheskomu rostu» (MTDE 2020). 